\title{
Measurement of the effectiveness of an HIV/AIDS intervention programme on knowledge, attitudes, and behaviour of the South African Polise Service employees
}

\author{
L Cherian \\ Educational Psychology, School of Education, University of Limpopo
}

LS Maphoso, Ph D

SABC Office, Polokwane

\section{Kev words}

HIV/AIDS, Intervention, Attitude, Knowledge, Behaviour.

\section{Correspondence address}

Lily Cherian

\begin{abstract}
Curationis $32(4): 4-18$
This study investigated if there was any change in the HIV/AIDS knowledge, attitudes, and behaviour of the South African Police Service's (SAPS) employees of Limpopo province after attending the HIV/AIDS intervention programme. From a population of $(\mathrm{N}=108)$ employees, those who attended the HIV/AIDS awareness workshop participated as experimental group $(n=51)$ while those who attended the suicide prevention and disability workshop as control group $(n=57)$. Random sampling method was used to select the above sample. Both workshops were conducted at various places in Limpopo Province. Pre-tests were administered before the workshops while the post-tests were administered after the workshops. The results were analysed using 2 (Group: Experimental versus Control Group) x 2 (Time: Pre-test versus Post-test, a repeated measure) Analyses of Variances (ANOVA). The findings showed that there was a significant change in HIV/AIDS knowledge after employees have attended the HIV/AIDS awareness workshop. There was however no significant change in attitude and ehavior after the HIV/AIDS awareness programme. The study recommends that a one day workshop is not enough to change attitude and ehavior. It also recommends that a follow up in the form of delayed post-test is required to investigate if the ehavior of the members who promised to change positively had actually changed as ehavior changes cannot manifest in a one day workshop. This can also serve as a suggestion for further research.
\end{abstract}




\section{Introduction}

Background

AIDS is a pandemic that is posing major challenges in the world today (Chinery-Hesse, 2000:1). The Department of Health is tasked with the responsibility of coordinating HIV/AIDS strategies to all departments, including non-government institutions (Worldbank, 2001:2). Business institutions also have the duty to implement HIV/AIDS policy in their workplace. According to Government Communication and Information System (GCIS), (2003:2), all sectors of government and other stake holders in civil society should be involved in combating HIV/ AIDS through intervention programmes. The problem facing the stakeholders in the HIV/AIDS fraternity is whether the implementation of these intervention programmes serves their purpose (i.e., combating the spread of HIV/AIDS, providing knowledge necessary to fight the pandemic, changing employees' attitudes towards infected and affected employees, changing employees' risky behavior towards sexual behavior, etc). There are also limited studies which investigated the employees' knowledge, attitude, and behavior change all in one study with a proper control group after the introduction of HIV/AIDS intervention programmes.

Problem statement: Strategies for combating HIV/AIDS within SAPS seem to be taking place. While the objective of these intervention programmes is to combat the spread of HIV/AIDS in the workplace, this objective cannot be achieved if employees' mindset is not changed. A verbal communication with Beukes, the HIV/AIDS Programme Manager in the SAPS in the Limpopo Province, indicated that there was no exact statistics or feedback regarding the HIV/AIDS.

Research questions: Do the interventions add HIV/AIDS knowledge to the employees in South Africa Police Service? Do they change attitude of the South African employees towards HIV/ AIDS related issues? Do these interventions change behaviour towards HIV/AIDS related issues? Would these changes be significantly higher than changes that might occur due to the passage of time?

\section{Purpose of the investigation}

Therefore, the purpose of this study is to find out whether HIV/AIDS interventions programmes change HIV/AIDS knowledge, attitudes, and behavior.

\section{Objectives}

To identify whether affective factors (knowledge, attitude, and behaviour) differ significantly among SAPS employees who have attended the HIV/ AIDS intervention programme and those who have not?

\section{Earlier studies on HIV/AIDS intervention programme, Knowledge, Attitudes,and Behaviour}

HIV/AIDS intervention programmes

The purpose of an intervention programme is to change something in order to help. Both international and local studies reveal that HIV/AIDS intervention programmes are aimed at changing the spread and the consequences of HIV/AIDS. Results from Swanepoel (2005:151) indicated that individuals who have received HIV/ AIDS prevention information are more likely to use protections (condoms) during sexual intercourse, ask their partners about their HIV status, be tested for HIV themselves, and know where to go for help regarding HIV issues. Swanepoel also concluded that HIV/ AIDS prevention information therefore contributed positively to HIV/AIDS prevention behaviour.

The HIV/AIDS intervention programme can help in reducing the unprotected sex and HIV/AIDS risk related behaviour among people. Using a Prevention Marketing Initiative (PMI) in a HIV risk-reduction workshop as an intervention in controlling the spread of HIV/AIDS in five United States sites (Nashville, Tennessee; Newark, New Jersey; Northern Virginia; Phoenix, Arizona; and Sacramento, California), Kennedy, Mizuno, Hoffman, Baune, \& Strand, (2000:236) found the reduced likelihood of unprotected sex among participants. In terms of risk related behaviour, Sikkema, Winett, \& Lombard, (1995:155) discovered that there were encouraging results regarding the effectiveness of a behavioural skills training program in increasing knowledge, belief, and skill related to HIV risk behaviour reduction.

Kuhn, Steinberg, \& Mathews, (1994:163) used classroom based activi- ties such as information session on HIV/AIDS, open discussion on HIV/ AIDS, and integration of AIDS contents as HIV/AIDS awareness programme to 276 students whose age ranged from 12 to 30 years in their study of the effect of an HIV/AIDS programme. A questionnaire which was translated from English to Xhosa was used to investigate the effect of the program on knowledge, attitude, and behaviour. The results also confirmed the relationship between the HIV/AIDS intervention programme and the three affective factors. They showed that the program greatly improved students' knowledge of HIV transmission and prevention; increased level of acceptance of people with AIDS (attitude), and had a small impact on behavioural intention.

Turner, Garrison, Korpita, Waller, Addy, Hill, \& Mohn, (1994:270) maintained that the knowledge, attitude, and behaviour scores for all students in the university were significantly higher than those not enrolled in the seminar aimed at promoting responsible sexual behaviour. Between, pre- and post-intervention, there was a notable significant increase in knowledge and behaviour score for all students enrolled and not for students who did not enroll. Seven hundred and eighty-six students completed anonymous, self reported questionnaires that focused on sexual behaviour, as well as knowledge, and attitude regarding sexual behaviour.

The HIV/AIDS intervention can bolster the person's intention to change. This is evidenced in the work of MacNairSemands, Cody \& Simono (1997:734) when they investigated the effect of intervention on knowledge, attitude, and behaviour. They found that HIV course on college campus increased condom usage, the ability to discuss safer sex with partners, selection of sexual partners, and learning about HIV/AIDS. The majority of students reported making minor attempts at change prior to the course, and enrolled students made increased and more significant attempts to change in the duration of the HIV course.

HIV/AIDS intervention programmes can expose the individual to HIV/AIDS information and can encourage discussion on HIV/AIDS related issues. This 
was revealed after a six month implementation of the Non-Government Organisation (NGO) HIV/AIDS educational program in primary school children in Tanzania, where pupils from the HIV/AIDS intervention school reported exposure to AIDS information and discussing HIV/AIDS related issues significantly more frequently than pupils from the comparison school (Klepp, Ndeki, Seha, Hanna, Lyimo, Msuya, Irema, \& Schreiner, 1994:1160). Basen-Engquist (1994:412) also found that students in the Safer Sex Efficacy Workshop (SSE workshop) and those in the lecture on HIV (HIV lecture) improved more from pre-test to post-test in the intention to use condoms than participants in the unrelated topic - family violence lecture (FV lecture). After two months follow up, participants in the SSE workshop increased their frequency of condom use from pre-test to post-test more than those in the HIV lecture and FV lecture.

\section{Conceptual framework for the study}

HIV/AIDS awareness programme is one of the intervention programme that is widely used to change HIV/AIDS knowledge, attitude, and behaviour as explained in the following subections.

\section{Knowledge}

Reber (2001:380) defines knowledge as the body of information possessed by a person, or by group of persons or culture. It is the mental components that result from processes, be they innately given or experientially acquired. Knowledge is the remembering of previousiy learned material, which involves the recall of wide range of material from specific fact to complete theories, and it represents one of the levels of the learning outcome in the cognitive domain (Grinhund \& Linn, 1990:506).

\section{HIVIAIDS awareness programmes and knowledge change}

Researchers believe that HIV/AIDS intervention can improve one's knowledge related to HIV/AIDS. The components of HIV/AIDS awareness programmes include exhibitions and theatre productions on HIV/AIDS and STD themes, campaigns linked to World
AIDS Days, National Condom Week, or AIDS Memorial Day (Davies, Schneider, Rapholo, \& Everett, 1998:55). Kuhn et al. (1994:164), in their investigation of HIV/AIDS program on knowledge, found that students' level of knowledge about HIV transmission, prevention, and the course of the disease improved following the AIDS awareness programme as compared to the neighbouring schools in which no specific HIV/AIDS intervention programme took place. Educational programs in the United States do a better job of increasing absolute level of knowledge (Wierson \& Bright, 1996:261). This is also shared by Wierson and Bright (1996:262); and MacNair-Semands et al. (1997:735) when they averred that the goals of AIDS educational programs are to increase knowledge. It was also found that higher AIDS risk knowledge levels significantly predict more condom use in Zimbabwe, whereas this relationship was only marginally significant for the U.S. college students (Wierson \& Bright, 1996:263).

Jemmott, Jemmott, and Fong (1989:1535) reported that the HIV prevention group scored significantly higher in HIV reduction knowledge than those in the control group. HIV/ AIDS reduction knowledge can also help in reducing risk related to HIV/ AIDS issues. Using 157 inner city African American male adolescents from Philadelphia, Jemmott (1996:138) found that adolescents who received the HIV risk-reduction intervention subsequently had greater AIDS knowledge as compared with the adolescents in the control condition. Instruments used in this research included questionnaires which were completed before, immediately afterwards and three months after the intervention. Interventions included videotapes, games, and exercises designed to influence AIDS related knowledge, supportive of safer sex practices. Shapiro, Radeckie, Charchian, and Josephson (1999:24) observed that an HIV/AIDS high-risk individual has a greater knowledge about HIV/AIDS disease and is more likely to have been tested for HIV, and is more self confident. Using 319 college students in Orange County, California, the researchers found that participants who were concerned about the disease and who had taken an
AIDS education class had more knowledge of HIV/AIDS related issues than those who did not.

\section{Attitude}

According to McClintock (1972:108), Social Science is equated with the study of attitude, and that is the core concept of the study of psychology. Attitude is a tendency to respond in a particular way, in a particular situation to a particular object (Cattel, 1965:444). It is a mental predisposition to act that is expressed by evaluating a particular entity with some degree of favour or disfavour. An individual's attitude usually focuses on objects, people, or institutions. According to Saal \& Knight (1995:61) attitude is a relatively stable affective or evaluative disposition towards a specific person, situation, or other activities.

\section{HIV/AIDS awareness programme and attitude change}

HIV/AIDS awareness programmes that take the form of educational programmes and HIV/AIDS workshops and courses can have an effect on the attitude of individual regarding HIV/ AIDS related issues. Klepp, et al. (1994:1161) found that following the educational program, pupils attending intervention schools reported much more restrictive attitudes towards engaging in sexual intercourse than at baseline. Kuhn, et al. (1994:164) also, found that attitude of acceptance of people who are HIV positive improved due to HIV awareness programmes. The above findings are also supported by Wilry, Edwards, and Dilworth (1991:411) who found that attitude of the experimental group improved after attending an HIV/AIDS issues course while the control group's attitude about AIDS became more negative.

As indicated by Kuhn, et al. (1994:164), whether students can accept someone with AIDS into their class is an item of attitude towards HIV/AIDS. In their study, they maintained that although negative attitudes persisted following the programme, some students recognised that HIV could not be spread by being in a classroom with someone with HIV/AIDS, showing how positively HIV/AIDS intervention programme can affect attitude towards infected and affected people. The neighbouring 


\begin{tabular}{|c|c|c|c|c|}
\hline & & $\begin{array}{l}\text { HIV/AIDS awareness } \\
\text { workshop }\end{array}$ & $\begin{array}{l}\text { Suicide prevention \& } \\
\text { disability workshop }\end{array}$ & Total \\
\hline & & Count & Count & \\
\hline Gender & $\begin{array}{l}\text { Male } \\
\text { Female }\end{array}$ & $\begin{array}{l}25 \\
26\end{array}$ & $\begin{array}{l}38 \\
19\end{array}$ & $\begin{array}{l}63 \\
45\end{array}$ \\
\hline Rank & $\begin{array}{l}\text { Admin } \\
\text { Constable } \\
\text { Sergeant } \\
\text { Inspector } \\
\text { Captain } \\
\text { Superintendent }\end{array}$ & $\begin{array}{l}30 \\
3 \\
2 \\
7 \\
6 \\
3\end{array}$ & $\begin{array}{c}11 \\
13 \\
- \\
30 \\
2 \\
1\end{array}$ & $\begin{array}{c}41 \\
16 \\
2 \\
37 \\
8 \\
4\end{array}$ \\
\hline Rank & $\begin{array}{l}\text { Admin } \\
\text { Junior } \\
\text { Senior }\end{array}$ & $\begin{array}{c}30 \\
5 \\
16\end{array}$ & $\begin{array}{l}11 \\
13 \\
33\end{array}$ & $\begin{array}{l}41 \\
18 \\
49\end{array}$ \\
\hline Section & $\begin{array}{l}\text { Support } \\
\text { Detective } \\
\text { Operation }\end{array}$ & $\begin{array}{c}29 \\
9 \\
13\end{array}$ & $\begin{array}{c}23 \\
7 \\
26\end{array}$ & $\begin{array}{l}52 \\
16 \\
39\end{array}$ \\
\hline Area & $\begin{array}{l}\text { Provincial } \\
\text { Capricorn } \\
\text { Mopani } \\
\text { Vhembe } \\
\text { Waterberg }\end{array}$ & $\begin{array}{c}13 \\
8 \\
18 \\
- \\
12\end{array}$ & $\begin{array}{c}1 \\
6 \\
28 \\
22 \\
-\end{array}$ & $\begin{array}{l}14 \\
14 \\
46 \\
22 \\
12\end{array}$ \\
\hline Age & $\begin{array}{l}20-33 \\
34-43 \\
44 \text { and above }\end{array}$ & $\begin{array}{l}18 \\
22 \\
11\end{array}$ & $\begin{array}{l}17 \\
22 \\
18\end{array}$ & $\begin{array}{l}35 \\
44 \\
29\end{array}$ \\
\hline \multicolumn{2}{|c|}{ TOTAL NUMBER OF GROUP } & 51 & 57 & 108 \\
\hline
\end{tabular}

school of which the HIV/AIDS education programmes were not available did not experience the improvement. On the other hand, the use of facilitators who are HIV positive in the workshop can increase the positive attitudes towards people with HIV/AIDS (Walters, 1997:17). Andeki, Klepp, Seha, \& Leshbari (1994:190) claimed that people who had HIV/AIDS knowledge had positive attitude towards spending time with and taking care of people with AIDS than were less knowledgeable people. The above highlights the interdependence of the affective factors (e.g. knowledge and attitude) on HIV/ AIDS related issues.

\section{Behaviour}

Behaviour derives from the word behave, which is to do things in a particular way (Wehmeier, 2000:92). Behaviour as such, is the way a person, ani- mal or plants behave or function in a particular situation. Reber (2001:82) defined behaviour as a generic term covering acts, activities, responses, reaction, movements, processes, operation, or any measurable response of an organism. According to the World Book (1992:201), behaviour is the way human beings and other organisms act, and in Psychology and other behavioural sciences, behaviour is how a person's actions fit society's idea of right or wrong.

It results from a combination of many factors. Learning theories, as emphasized by McKenney, Lorion, and Zax (1976:161), provide many useful concepts with which to understand the etiology and maintenance of behaviour. Hjelle and Ziegler (1987:10) as such averred that learning becomes the central focus of interest for behaviourist.

\section{HIVIAIDS awareness programme and behaviour change}

MacNair-Semands, Cody \& Simono, (1997:736) maintained that an important aim of HIV course or intervention is not only to help students reduce risk behaviour, but also to help them to maintain safer sex behaviour they may already have initiated and making these part of a daily pattern. The goals of the health education intervention are to (a) to provide factual information regarding STD and AIDS as well as prevention strategies including abstention and safer sexual techniques; (b) to desensitize students regarding condoms, (c) to present practice communication skill and assertiveness techniques relative to potential sexual situations and relationships (Turner, et al. 1994:267). Davies et al. (1998:61) reiterated that an increase in the number of condoms distributed, occurring together with the 


\begin{tabular}{|c|c|c|c|c|c|c|}
\hline & \multicolumn{3}{|l|}{ Pre-test } & \multicolumn{3}{|c|}{ Post-test } \\
\hline & $\mathrm{N}$ & Mean & $\mathrm{SD}$ & $\mathrm{N}$ & Mean & $\mathrm{SD}$ \\
\hline Experimental Group & 51 & 7.51 & 2.26 & 51 & 8.78 & 1.79 \\
\hline \multirow[t]{3}{*}{ Control Group } & 56 & 6.67 & 2.02 & 56 & 7.09 & 1.92 \\
\hline & \multicolumn{3}{|l|}{ Pre-test } & \multicolumn{3}{|c|}{ Post-test } \\
\hline & $\mathrm{N}$ & Mean & $\mathrm{SD}$ & $\mathrm{N}$ & Mean & SD \\
\hline Experimental Group & 51 & 7.51 & 2.26 & 51 & 8.78 & 1.79 \\
\hline \multirow[t]{3}{*}{ Control Group } & 56 & 6.67 & 2.02 & 56 & 7.09 & 1.92 \\
\hline & \multicolumn{3}{|l|}{ Pre-test } & \multicolumn{3}{|c|}{ Post-test } \\
\hline & $\mathrm{N}$ & Mean & $\mathrm{SD}$ & $\mathrm{N}$ & Mean & SD \\
\hline Experimental Group & 51 & 7.51 & 2.26 & 51 & 8.78 & 1.79 \\
\hline \multirow[t]{3}{*}{ Control Group } & 56 & 6.67 & 2.02 & 56 & 7.09 & 1.92 \\
\hline & \multicolumn{3}{|l|}{ Pre-test } & \multicolumn{3}{|c|}{ Post-test } \\
\hline & $\mathrm{N}$ & Mean & $\mathrm{SD}$ & $\mathrm{N}$ & Mean & $\mathrm{SD}$ \\
\hline Experimental Group & 51 & 7.51 & 2.26 & 51 & 8.78 & 1.79 \\
\hline Control Group & 56 & 6.67 & 2.02 & 56 & 7.09 & 1.92 \\
\hline
\end{tabular}

decrease in the incidence of STD, could indicate that employees were changing their sexual behaviour as a result of education programmes.

Compared with the control women, the treatment women significantly increased self-efficacy, protective sexual behaviour, and prevention sexual behaviour after attending a HIV Prevention Intervention for low income African American women (Dancy, Marcantonio, \& Norr, 2000:113). HIV/ AIDS reduction programmes can also have an effect on the HIV/AIDS related behaviour. The results of a study by Jemmott (1996:138) revealed that adolescents who received the HIV risk-reduction intervention subsequently had reduced intention for HIV risk-associated behaviour as compared with the adolescents in the control condition.

However, Davies, et al. (1998) mentioned that information alone will not result in any behaviour changes required for reducing the risk of HIV transmission. People's skills and confidence need to develop, so that they can behaviourally protect themselves.
They should be educated to take charge of their own life and destiny.

\section{Research design and procedure}

\section{Research design}

This study used a quantitative research where one emphasises the quantification of constructs, and believes that the duly way of measuring the properties of phenomena is through quantitative measurement (Babbie \& Mouton, 2001:49). The study was a causal-comparative cross-sectional survey where all data were collected at the same time. It was casual comparative because participants were not randomly assigned to the experimental and control conditions. Instead existing groups were compared. This design is ideally suited for a descriptive and predictive research associated with correlative studies (Steyn \& Maphoso, 2005:245). McMillan and Schumacher (1997:281) maintained that descriptive results can be used to investigate relationships.

\section{Population and Sample size}

To investigate whether the HIV/AIDS awareness programme in the SAPS can change the employees' knowledge, attitude, and behavior. In 2006, a minimum number of 125 employees were expected to attend the workshop. Workshops were conducted in Capricorn, Waterburg, Mopani and Vhemba area. The HIV/AIDS awareness workshop in this case, was the treatment condition. The study used the SAPS employees in the Limpopo Province as the study's population $(\mathrm{N}=108)$. The sample size of approximately fifty one (51) employees ( 25 males and 26 females) whose ages ranged between 20 to 55 and attended the HIV/AIDS awareness workshops comprised the experimental group. Those who attended suicide prevention and disability workshops comprised the control group. This group consisted of fifty seven (57) members ( 38 males and 19 females). The control group is the group of participants that served as a standard of comparison for determining if the treatment condition produced any effect (see Table1).

\section{Ethical measures}

In view of ethical issues, the following received particular attention by the 
Table 3: Percentage response on HIVIAIDS knowledge, before and after HIVIAIDS awareness workshop

\begin{tabular}{|c|c|c|c|c|}
\hline No & Statement & True & False & D/know \\
\hline $\mathrm{K} 1$ & Coughing and sneezing do not spread HIV & $\begin{array}{l}62.7 \\
80.4\end{array}$ & $\begin{array}{l}25.5 \\
15.7\end{array}$ & $\begin{array}{c}11.8 \\
3.9\end{array}$ \\
\hline K2 & $\begin{array}{l}\text { A person can contract HIV virus by sharing a glass of } \\
\text { water with someone who is HIV positive }\end{array}$ & $\begin{array}{l}9.8 \\
8.0\end{array}$ & $\begin{array}{l}84.3 \\
90.0\end{array}$ & $\begin{array}{l}5.9 \\
2.0\end{array}$ \\
\hline K3 & $\begin{array}{l}\text { Withdrawing the penis before a climax (ejaculates) } \\
\text { prevents a woman from contracting HIV during sex }\end{array}$ & $\begin{array}{l}15.7 \\
9.8\end{array}$ & $\begin{array}{l}72.5 \\
82.4\end{array}$ & $\begin{array}{c}11.8 \\
7.8\end{array}$ \\
\hline K4 & A man can contract HIV if he has anal sex with a man & $\begin{array}{l}70.6 \\
80.4\end{array}$ & $\begin{array}{l}17.6 \\
15.7\end{array}$ & $\begin{array}{c}11.8 \\
3.9\end{array}$ \\
\hline K5 & $\begin{array}{l}\text { Condoms are less than fifty percent safe for the pre- } \\
\text { vention of HIV/AIDS infection }\end{array}$ & $\begin{array}{l}31.4 \\
31.4\end{array}$ & $\begin{array}{l}58.8 \\
62.7\end{array}$ & $\begin{array}{l}9.8 \\
5.9\end{array}$ \\
\hline K6 & $\begin{array}{l}\text { All pregnant women infected with HIV will have ba- } \\
\text { bies born HIV positive }\end{array}$ & $\begin{array}{l}33.3 \\
31.3\end{array}$ & $\begin{array}{l}58.8 \\
66.7\end{array}$ & $\begin{array}{l}7.9 \\
2.0\end{array}$ \\
\hline K7 & $\begin{array}{l}\text { Showering and washing your genitals after sex can } \\
\text { reduce the chances of being infected with HIV }\end{array}$ & $\begin{array}{c}15.7 \\
3.9\end{array}$ & $\begin{array}{l}70.6 \\
90.2\end{array}$ & $\begin{array}{c}13.7 \\
5.9\end{array}$ \\
\hline K8 & $\begin{array}{l}\text { Fruits, vegetable, and Mopani worms can help a pa- } \\
\text { tient living with HIV/ADS }\end{array}$ & $\begin{array}{l}80.4 \\
86.3\end{array}$ & $\begin{array}{l}11.8 \\
9.8\end{array}$ & $\begin{array}{l}7.8 \\
3.9\end{array}$ \\
\hline K9 & $\begin{array}{l}\text { I know of where and how I can do HIV testing and } \\
\text { counseling, and the consequences of my testing }\end{array}$ & $\begin{array}{l}84.3 \\
94.1\end{array}$ & 3.9 & $\begin{array}{c}11.8 \\
5.9\end{array}$ \\
\hline K10 & I know about peer educators in my educators & $\begin{array}{l}76.5 \\
90.2\end{array}$ & 5.9 & $\begin{array}{l}17.6 \\
21.4\end{array}$ \\
\hline \multirow[t]{2}{*}{ K11 } & $\begin{array}{l}\text { People are likely to contract HIV by deep kissing } \\
\text { (puttingstheir tongue in their partners' mouth) if their } \\
\text { partners are HIV positive. }\end{array}$ & $\begin{array}{l}32.0 \\
56.8\end{array}$ & $\begin{array}{l}62.0 \\
41.2\end{array}$ & $\begin{array}{l}6.0 \\
2.0\end{array}$ \\
\hline & $\begin{array}{l}\text { Total (pre) } \\
\text { Total (post) }\end{array}$ & $\begin{array}{c}\text { Correct } \\
68.3 \\
80\end{array}$ & $\begin{array}{l}\text { Wrong } \\
21.1 \\
15.1\end{array}$ & $\begin{array}{c}\mathrm{D} / \mathrm{know} \\
10.5 \\
5.8\end{array}$ \\
\hline
\end{tabular}

NB: Bolded answers are considered the "correct" answers for each question

researchers: informed consent, no violation of privacy, statement of cooperation with collaboration, release of publication of findings, and restoration of subjects or respondents wherever possible and necessary. Permission from Limpopo SAPS provincial authority and the Ethics Committee of the University of Limpopo was also obtained.

\section{Research instrument Questionnaire}

The instrument used in this study was a questionnaire called HIV/AIDS Knowledge, Attitude, and Behaviour Questionnaire (see Appendix A). The
HIV/AIDS Knowledge, Attitude, and Behaviour Questionnaire (HAKABQ) were adopted, and it consisted of items related to HIV/AIDS knowledge, attitude, and behaviour. The knowledge and attitude items were adopted from Carey and Schroder's (2002:172-182), HIV Knowledge Questionnaire (HIVKQ-18). The questionnaire was suitable for low income men and women and was internally consistent, stable, sensitive to the change resulting from intervention, and also suitable for low literary group. The knowledge and attitude questionnaire was also adopted by the University of Limpopo, Health
Behaviour Research Unit during the Development and Evaluation of an HIVRisk Programme for the First Entering Students in the university in 2001. The behaviour items on the other hand, were adopted from Wayers (2002:9) HIV/ AIDS Behaviour Questionnaire. The questionnaire was used to assess SAPS members who attended the HIV/AIDS awareness workshops (before and after the workshop sessions).

\section{Validity and reliability of the HABAKQ}

For content validity, the questionnaire was sent to peer educators, HIV/AIDS 
Table 4: Pre- test and post-test of HIVIAIDS attitudes scores for experimental and control groups

\begin{tabular}{|l|l|l|l|l|l|l|}
\hline & Pre-test & & & Post-test & & \\
\cline { 2 - 7 } & $\mathbf{N}$ & Mean & SD & N & Mean & SD \\
\hline Experimental Group & 51 & 37.90 & 5.01 & 51 & 38.67 & 5.17 \\
\hline Control Group & 57 & 36.47 & 5.63 & 56 & 37.07 & 6.45 \\
\hline
\end{tabular}

coordinators, the section head of the Social Work Services and the commander in the EAS of the SAPS who confirm that the questionnaire contained items of HIV/AIDS knowledge, attitude, and behaviour related issues. Face validity is the degree to which it appears, on the basis of subjective evaluation, whether the test serves its purpose (Huysamen, 1995:42). It is ultimately a matter of judgement (Cherian, 1996:138). Specialists in the HIV/AIDS issues, researchers, and peer educators confirm that the HAKABQ seemed to be relevant in collecting data related to HIV/AIDS knowledge, attitude, and behaviour.

According to Rosnow and Rosenthal (1996:122) reliability is the consistency or stability where something can be repeated and be confirmed by further competent measurements. The HIVKQ-18 provided strong levels of internal consistency and test-retest reliability. The internal consistencies across samples ranged from .75 to .89 , easily exceeding the .70 standard recommended (Rosnow \& Rosenthal, 1996:122). It has the alpha $=.91$ and is stable over one $(r=.83$, two- $3=.91$, and twelve-week $(r=.90)$ intervals. The testretest correlation was .83 , which provided evidence of stability.

\section{Pilot study}

The pilot study was done on all five HIV/AIDS coordinators in the SAPS during their annual meeting. From the pilot study, it was found that items that read 'Traditional medicines are a waste of time in the HIV/AIDS intervention' was categorised under HIV/ AIDS behaviour. It was then put in the HIV/AIDS attitude section, as it seeks the judgement of the participant, and not his/her behaviour. There was an item in the HIV/AIDS knowledge section that read 'a man can contract HIV if he has sex with a man'. This ques- tion was found to be wide and as such anal was added before sex and the items read as follow: 'a man can contract HIV if he has anal sex with a man.'

\section{Variables}

This research used two kinds of variables, namely independent variables and dependent variables.

\section{Independent variables}

Independent variables are variables that the experimenter changes within a defined range. They are the variables that can be manipulated by the experimenter, which the experimenter or investigator is interested in its possible effect. In this study the HIV/AIDS awareness workshop is the independent variable.

\section{Dependent variables}

Dependent variables are variables that measure the influence of the independent variable. Behaviour, attitude and behaviour are dependent variables. It was hypothesised that their change depended on the HIV/AIDS intervention programme, in this case the SAPS' HIV/AIDS awareness workshop.

\section{Data collection}

Permission was asked and granted from the provincial SAPS authority to conduct the research in the SAPS. On the date of the workshops (HIV/AIDS awareness, suicide prevention, and disability), the coordinators of the workshop gave the researcher/s opportunity to administer the questionnaire. The researcher/s explained to the participants the purpose of the questionnaire and all that was required of them. Participants were informed that participation was voluntary, and that the results would only be used for the study purpose and nothing else. They were also requested to sign consent form before participation. The participants were told about the confidentiality of the process, and that anyone could withdraw from participating at any time if he/she desired. They were told that they would be given the pre-test before the workshop, and the post-test after the workshop. The same procedure was followed at the end of the workshop, when the post-tests were administered.

\section{Statistical analysis}

This research study used an Analysis of Variance (ANOVA) to analyse if there were statistically significant changes in knowledge, attitudes, and behaviour before and after members attended the HIV/AIDS awareness, suicide prevention, and disability workshops. It was also used to analyse if there were significant differences between members who attended HIV/AIDS workshop as a research group, and those who attended suicide prevention and disability workshops as a control group.

\section{Results and discussion}

In order to investigate possible differences in HIV/AIDS knowledge, attitudes, and behaviour on pre-test and post-test between experimental and control groups, ANOVAs were computed. Each ANOVA had group (2: experimental versus control group) as a between-subjects variable and time ( 2 : pre-test versus post-test) as a within subjects-variable. Separate ANOVAs were computed

\section{HIVIAIDS knowledge and HIVI AIDS intervention programme}

The following null hypothesis was tested:

Hol There will not be a statistically significant change in HIV/AIDS knowledge after employees have attended HIV/ADS intervention programme.

The 2 (Group: Experimental versus Control) $\times 2$ (Time: Pre-test versus post- 


\begin{tabular}{|c|c|c|c|c|c|}
\hline ItemNo. & ATTTTUDE & \multicolumn{4}{|c|}{ RATING } \\
\hline \multirow[b]{2}{*}{ Al } & \multirow[b]{2}{*}{ Using a condom takes the "wonder" of sex } & $\mathbf{Y}$ & $\mathbf{y}$ & $\mathbf{n}$ & $\mathbf{N}$ \\
\hline & & $\begin{array}{l}19.6 \\
22.0\end{array}$ & $\begin{array}{l}15.2 \\
10.0\end{array}$ & $\begin{array}{l}19.6 \\
20.0\end{array}$ & $\begin{array}{l}45.8 \\
48.0\end{array}$ \\
\hline A2 & $\begin{array}{l}\text { If I do HIV testing, people will discriminate me } \\
\text { if they found that I am HIV positive }\end{array}$ & $\begin{array}{l}8.0 \\
22.0\end{array}$ & $\begin{array}{l}34.0 \\
18.0\end{array}$ & $\begin{array}{l}16.0 \\
10.0\end{array}$ & $\begin{array}{l}42.0 \\
50.0\end{array}$ \\
\hline A3 & $\begin{array}{l}\text { A condom is not necessary when you and your } \\
\text { partner agree to have sex with anyone else }\end{array}$ & $\begin{array}{l}36.0 \\
45.1\end{array}$ & $\begin{array}{l}18.0 \\
17.6\end{array}$ & $\begin{array}{c}14.0 \\
7.8\end{array}$ & $\begin{array}{l}32.0 \\
29.5\end{array}$ \\
\hline A4 & $\begin{array}{l}\text { I do not want to do testing because the person } \\
\text { who conduct the testing will make my results } \\
\text { known to my colleagues }\end{array}$ & $\begin{array}{l}7.8 \\
10.0\end{array}$ & $\begin{array}{c}11.8 \\
6.0\end{array}$ & $\begin{array}{l}21.6 \\
22.0\end{array}$ & $\begin{array}{l}58.8 \\
62.0\end{array}$ \\
\hline A5 & $\begin{array}{l}\text { I like attending HIV/AIDS meetings, work- } \\
\text { shops and seminars }\end{array}$ & $\begin{array}{l}76.4 \\
80.4\end{array}$ & $\begin{array}{l}19.6 \\
15.6\end{array}$ & $\begin{array}{l}2.0 \\
2.0\end{array}$ & $\begin{array}{l}2.0 \\
2.0\end{array}$ \\
\hline A6 & $\begin{array}{l}\text { Using a condom show my partner that I care } \\
\text { about him/her }\end{array}$ & $\begin{array}{l}76.0 \\
78.4\end{array}$ & $\begin{array}{l}16.0 \\
11.8\end{array}$ & $\begin{array}{l}4.0 \\
5.9\end{array}$ & $\begin{array}{r}4.0 \\
3.9\end{array}$ \\
\hline A7 & People who use condoms sleep around a lot & $\begin{array}{l}29.4 \\
19.6\end{array}$ & $\begin{array}{l}9.8 \\
11.8\end{array}$ & $\begin{array}{l}13.7 \\
13.7\end{array}$ & $\begin{array}{l}47.1 \\
54.9\end{array}$ \\
\hline A8 & $\begin{array}{l}\text { I can use the same toilet facilities with the HIV } \\
\text { positive people }\end{array}$ & $\begin{array}{l}74.0 \\
84.3\end{array}$ & $\begin{array}{l}12.0 \\
11.7\end{array}$ & 2.0 & $\begin{array}{c}14.0 \\
2.0\end{array}$ \\
\hline A9 & $\begin{array}{l}\text { Traditional medicines are a waste of time in the } \\
\text { HIV/AIDS intervention }\end{array}$ & $\begin{array}{l}31.4 \\
35.3\end{array}$ & $\begin{array}{l}13.7 \\
19.6\end{array}$ & $\begin{array}{c}19.6 \\
7.8\end{array}$ & $\begin{array}{l}35.3 \\
37.3\end{array}$ \\
\hline A10 & $\begin{array}{l}\text { Do you think peer educators can improve HIV/ } \\
\text { AIDS awareness }\end{array}$ & $\begin{array}{l}80.4 \\
80.4\end{array}$ & $\begin{array}{l}17.6 \\
13.7\end{array}$ & 3.9 & $\begin{array}{l}2.0 \\
2.0\end{array}$ \\
\hline A11 & $\begin{array}{l}\text { People who are HIV positive should mix with } \\
\text { other people }\end{array}$ & $\begin{array}{l}86.0 \\
88.2\end{array}$ & $\begin{array}{c}10.0 \\
7.8\end{array}$ & $\begin{array}{l}2.0 \\
2.0\end{array}$ & $\begin{array}{l}2.0 \\
2.0\end{array}$ \\
\hline \multirow[t]{2}{*}{$\mathrm{A} 12$} & $\begin{array}{l}\text { I can die earlier if I know that I am HIV positive, } \\
\text { than if I do not know my HIV status }\end{array}$ & $\begin{array}{l}17.6 \\
19.6\end{array}$ & $\begin{array}{l}9.8 \\
7.9\end{array}$ & $\begin{array}{l}7.9 \\
3.9\end{array}$ & $68.6^{64.7}$ \\
\hline & $\begin{array}{l}\text { Total (pre) } \\
\text { Total (post) }\end{array}$ & \multicolumn{2}{|c|}{$\begin{array}{c}\text { Strongly positive } \\
59.9 \\
63.5\end{array}$} & \multicolumn{2}{|c|}{$\begin{array}{c}\text { Strongly negative } \\
14.5 \\
15.5\end{array}$} \\
\hline
\end{tabular}

NB: Bolded answers are considered the "correct" answers for each question

test, a repeated measure) Analysis of Variance (ANOVA) was computed on knowledge scores. There was a significant main effect of time, $F(1,105)=$ $21.73, p=.000$. There also was a significant main effect of group, $F(1,105)=$ $14.07, p=.000$. The experimental group scored higher than the control group, and knowledge scores were significantly higher on the post-test than the pre-test (see Table 2). There also was a significant interaction between time and group, $F(1,105)=5.03, p=.027$. The null hypothesis was therefore, rejected.

HIV/AIDS attitudes and HIV/AIDS intervention programme

The following null hypothesis was tested:

Ho2 There will not be a statistically significant change in HIV/AIDS attitudes after employees have attended HIV/ADS intervention pro- gramme.

The 2 (Group: Experimental versus Control) $\times 2$ (Time: Pre-test versus posttest, a repeated measure) ANOVA was computed on attitude scores. There was not a significant main effect of time, $F(1,105)=2.05, p=.156$. There also was not a significant main effect of group, $F(1,105)=2.24, p=.137$. There was not a significant interaction between time and group. $F(1,105)=$ 


\begin{tabular}{|c|c|c|c|c|c|c|}
\hline & \multicolumn{3}{|l|}{ Pre-test } & \multicolumn{3}{|l|}{ Post-test } \\
\hline & $\mathbf{N}$ & Mean & SD & $\mathbf{N}$ & Mean & SD \\
\hline Experimental Group & 51 & 23.59 & 3.88 & 51 & 26.25 & 2.74 \\
\hline Control Group & 57 & 23.44 & 3.68 & 55 & 25.58 & 3.93 \\
\hline
\end{tabular}

$0.06, p=.802$. Therefore, there was not sufficient evidence that the null hypothesis could be rejected. Table 4 gives the Pre-test and post-test HIV/AIDS attitude scores for experimental and control groups.

HIV/AIDS behaviour and HIV/AIDS intervention programme

The following null hypothesis was tested:

Ho3 There will not be a statistically significant change in HIV/AIDS behaviour after employees have attended HIV/ADS intervention programme.

The 2 (Group: Experimental versus Control) $\times 2$ (Time: Pre-test versus posttest, a repeated measure) ANOVA was computed on behaviour scores. There was a significant main effect of time, $F$ $(1,104)=62.86, p=.000$. Participants got higher behaviour scores on the post-test than the pre-test. There was no significant main effect of group, $F$ $(1,104)=0.51, p=.478$, and no significant interaction between time and group, $F(1,104)=0.53, p=.468$. Therefore, there was not sufficient evidence that the null hypothesis could be rejected. Table 6 shows Pre-test and posttest of HIV/AIDS behaviour scores for experimental and control groups.

\section{Conclusions,}

\section{recommendations, limitations and future \\ research}

\section{Conclusions}

Table 8 summarises the findings of the present study with regard to changes in knowledge, attitude, and behaviour. Each of these is discussed in the sections that follow.

\section{Knowledge change}

It was found that knowledge changed in relation to the actual intervention as indicated by post-test being greater that pre-test. It appeared that the one day HIV/AIDS awareness workshop was effective in changing knowledge and that the experimental groups also had higher scores than the control group.

\section{Attitude change}

In the present study, attitude did not change after the HIV/AIDS awareness workshop. Whatever differences there were in attitude initially were the differences later, and the workshop appeared to have little to no effect in changing people's attitudes.

\section{Behaviour change}

Both the experimental and the control groups said their behaviour had changed after the HIV/AIDS intervention. This was indicated by the posttest being greater than the pre-test. Therefore concluding that the HIV/ AIDS awareness workshop changed the HIV/AIDS behaviour would be improper.

\section{Recommendations}

Government institutions should employ HIV/AIDS intervention programmes in the form of HIV/AIDS awareness workshops, where they educate fellow employees on other strategies that were created to change their knowledge towards the pandemic's related issues. Perhaps it takes much more than a one day workshop to impact people's attitudes and behaviour.

Prior counseling to senior and administrative employees is recommended.

Special skills possessed by the social workers, psychologists, and chaplains, who were presenters of the HIV/AIDS awareness workshops, can be used to change the attitude of employees in order to motivate them and to make the workshop fruitful for them.

\section{Limitations for the study}

The researcher did not manage to get responses from some of the targeted workshops. The HIV/AIDS awareness workshop in the Vhembe District did not take place and as such they were not included in this study. The Vhembe District is predominantly Venda speaking employees. The Venda population is one of the official ethnic groups in the Limpopo Province. The exclusion of this ethnic group may mean that the results of this study's findings may not generalise to all ethnic groups in the South African Police Service of the Limpopo Province.

Attitude is not something that develops in one day. It is made up of events, views, and judgments that develop over time and as such it is not easy to change it in a one day workshop like the HIV/ AIDS awareness workshop. Attitude can be changed by intervention that last for weeks or months, and the impact of such intervention would need to be evaluated continuously. The time frame between the pre-test and posttest of this study was quite short.

Behaviour change in this study was represented by what the employees did previously and the intention of the participants to change what they had been doing, and not the employees' actual behaviour. The actual behaviour could manifest after weeks, months, or years. It would have been better to give people the very same questionnaire as in the pre-test. Due to time constrains and financial limitations, these follow ups could not materialise.

\section{Suggestions for further research}

Intention to do something probably overestimates people's actual behaviour. The research could investigate whether the members were behaving the way they had claimed they intended to behave by conducting delayed post-tests (i.e., one month after 

workshop

\begin{tabular}{|c|c|c|c|c|}
\hline \multirow[t]{2}{*}{ ITEMNO. } & \multirow[t]{2}{*}{ BEHAVIOUR } & \multicolumn{3}{|l|}{ RATING } \\
\hline & & Not at all & Sometimes & Always \\
\hline $\mathrm{B} 1$ & I use condom during sex & $\begin{array}{l}8.0 \\
3.9\end{array}$ & $\begin{array}{l}32.0 \\
15.7\end{array}$ & $\begin{array}{l}60.0 \\
80.4\end{array}$ \\
\hline B2 & I have done HIV test in the past year & $\begin{array}{l}37.3 \\
12.0\end{array}$ & $\begin{array}{l}37.3 \\
30.0\end{array}$ & $\begin{array}{l}25.5 \\
58.0\end{array}$ \\
\hline B3 & I have many sexual partners & $\begin{array}{l}85.4 \\
94.0\end{array}$ & $\begin{array}{l}10.4 \\
-\end{array}$ & $\begin{array}{l}4.2 \\
6.0\end{array}$ \\
\hline B4 & $\begin{array}{l}\text { I usually attend HIV/AIDS meetings, } \\
\text { workshops and seminars }\end{array}$ & $\begin{array}{l}19.6 \\
2.0\end{array}$ & $\begin{array}{l}41.2 \\
12.2\end{array}$ & $\begin{array}{l}39.2 \\
85.7\end{array}$ \\
\hline B5 & I avoid risky sexual partners & $\begin{array}{l}14.0 \\
6.1\end{array}$ & $\begin{array}{l}14.0 \\
2.0\end{array}$ & $\begin{array}{l}72.0 \\
91.8\end{array}$ \\
\hline B6 & $\begin{array}{l}\text { I only have sex with an HIV negative } \\
\text { partner who only has sex with me }\end{array}$ & $\begin{array}{l}29.8 \\
18.0\end{array}$ & $\begin{array}{l}17.0 \\
16.0\end{array}$ & $\begin{array}{l}53.2 \\
66.0\end{array}$ \\
\hline B7 & $\begin{array}{l}\text { I talk with my sexual partner about HIV/ } \\
\text { IDS before having sex with him/her }\end{array}$ & $\begin{array}{l}10.0 \\
5.7\end{array}$ & $\begin{array}{l}24.0 \\
13.7\end{array}$ & $\begin{array}{l}66.0 \\
80.4\end{array}$ \\
\hline B8 & $\begin{array}{l}\text { I always withdraw and wash my geni- } \\
\text { tals (private parts) after climaxing (ejacu- } \\
\text { lation) }\end{array}$ & $\begin{array}{l}36.0 \\
33.3\end{array}$ & $\begin{array}{l}26.0 \\
11.8\end{array}$ & $\begin{array}{l}38.0 \\
54.9\end{array}$ \\
\hline B9 & $\begin{array}{l}\text { I want to be involved with HIV/AIDS } \\
\text { activities }\end{array}$ & $\begin{array}{l}15.7 \\
6.0\end{array}$ & $\begin{array}{l}25.5 \\
8.0\end{array}$ & $\begin{array}{l}58.8 \\
86.0\end{array}$ \\
\hline $\mathrm{B} 10$ & $\begin{array}{l}\text { I only have sex with people who had an } \\
\text { HIV test }\end{array}$ & $\begin{array}{l}40.0 \\
20.0\end{array}$ & $\begin{array}{l}34.0 \\
16.0\end{array}$ & $\begin{array}{l}26.0 \\
64.0\end{array}$ \\
\hline \multirow[t]{2}{*}{ B11 } & I eat fruits and vegetables regularly & $\begin{array}{l}2.0 \\
2.0\end{array}$ & $\begin{array}{l}22.4 \\
11.8\end{array}$ & $\begin{array}{l}75.5 \\
86.3\end{array}$ \\
\hline & $\begin{array}{l}\text { Total (pre) } \\
\text { Total (post) }\end{array}$ & $\begin{array}{l}\text { Positivebehaviour } \\
54.5 \\
77.1\end{array}$ & $\begin{array}{l}\text { Sometimes } p / n \\
25.8 \\
12.5\end{array}$ & $\begin{array}{l}\text { Negativebehaviour } \\
19.7 \\
9.9\end{array}$ \\
\hline
\end{tabular}

NB: Bolded answers are considered the "correct" answers for each question

the workshop). This would make the pre-test and post-test more similar and might be the indicator of the actual behaviour change. A follow up on the members of the SAPS who attended these HIV/AIDS workshops and who were sampled for this study could be conducted to investigate whether these members actually did those things they intended to do. The follow up also could investigate whether participants still held the increased knowledge they had displayed at the end of the work- shop.

Future research also should look at other problems that can be derived from the implementation of the HIV/AIDS intervention programmes. These intervention programmes may not only affect the individuals' knowledge, attitude, and behaviour, but they can also affect the employees' family, economic, and social situations. Further research into the influence of HIV/AIDS awareness workshops or other intervention programmes into the family life is therefore suggested.

\section{References}

ANDEKI, SS; KLEPP, KI; SEHA, AM \& LESHBARI,MT 1994: Exposure to HIV/AIDS information, AIDS knowledge, perceived risk and attitude toward people with AIDS among primary school-children in Northern Tanzania. AIDS Care, 6(2), 183-191.

BABBIE, E \& MOUTON, J 2001: The 


\begin{tabular}{|l|l|l|}
\hline Depended Variable & Independent variables & Results \\
\hline Knowledge & Time (Pre \& Post) tests & $\begin{array}{l}\text { Post-test }>\text { Pre-test (significantly more change } \\
\text { for the experimental group than the control } \\
\text { group) }\end{array}$ \\
\hline Attitude & Groups (Experimental \& Control) & Experimental > control \\
\hline Behaviour & Time (Pre \& Post) tests & No significant difference \\
& Groups (Experimental \& Control) & No significant difference \\
\hline Gime (Pre \& Post) tests & Post-test > Pre-test \\
No significant difference (Both groups im- \\
proved)
\end{tabular}

Practice of Social Research. Cape Town: Belmont

BASEN-ENGQUIST, K 1994: Evaluation of a Theory-Based HIV Prevention Intervention for College Students. AIDS Education and Prevention. 6(5), $412-424$.

CAREY,MD; MORRISON-BEEDY,D \& JOHNSON BT 1997: The HIV Questionnaire: Development and evaluation of a reliable, valid, and practical self administered questionnaire (HIVKQ-18). Aids and Behaviour. 1, 61-74.

CAREY, MD \& SCHRODER, KEE 2002: Development and Psychometric Evaluation of the brief HIV knowledge questionnaire. AIDS Education and Prevention. 14(2), 172-182.

CATTEL, RB 1965: The scientific analysis on personality. Penguin: Baltimore.

CHERIAN, L 1996: The attitude of Standard 10 pupils towards Science in Erstwhile Lebowa: Sovenga: University of the North. (Unpublished Doctoral Thesis)

CHINERY-HESSE, M 2000: HIV/ AIDS in Africa. http://www.heartintl.net/HE Accessed on 02 March 2005.

CLARK, PA 2006: Mother-to-child transmission of HIV in Botswana: An ethical perspective on mandatory testing. Developing World Bioethics. 6(1),
$1-12$.

DANCY, LB; MARCANTONIO, R \& NORR, K 2000: The long-term effectiveness of an HIV Prevention Intervention for low-income African American women. AIDS education and Prevention. 12(2), 113-125.

DAVIES, S; SCHNEIDER, M; RAPHOLO, G; \& EVERETT, D 1998: Guideline for Developing a workplace policy and programme on HIV/AIIDS and STDs. Pretoria: Department of Health.

Government Communication and Information System (GCIS) 2003: Update on the national HIV and AIDS programme., http://www.gcis/za /does/ index.html. Accessed on $02 \mathrm{March} 2005$.

GRINHUND, NE \& LINN, RL 1990: Measurement and Evaluation in Teaching, $2^{\text {nd }}$ ed. Singapore: Macmillan Publishing.

HEALTH \& WELFARE MINISTRIES 2006: Support Group: Places of Healing. http://www.UNAIDSs.org. Accessed on $7^{\text {th }}$ July 2006.

HJELLE, LA \& ZIEGLER, DJ 1981: Personality Theories: Basic Assumption, Research, and Applications. Singapore: McGraw-Hill Book Co.

HUYSAMEN, GK 1995: Psychological Measurement: An introduction with South African Examples.

Pretoria: Academic.
JEMMOTT, JB 1996: Social Psychological Influence on HIV Risk Behaviour Among African American Youth. Claremont Symposium on Applied Psychology. London: Sage Publication.

JEMMOTT, JB; JEMMOTT, LS \& FONG $T$ 1989: Abstinence and Safer Sex HIV Risk-Reeducation Intervention for African American Adolescents: A randomized Control Trial. Journal of the American Medical Association (JAMA), 279(19), 1529-1536.

KENNEDY, MG; MIZUNO, Y; HOFFMAN, R; BAUNE, C \& STRAND, J 2000: The effect of tailoring a model HIV Prevention Program for local adolescent target audience. AIDS Education and Prevention 12(3), 225-238.

KLEPP, K; NDEKI, S; SEHA, AM; HANNA, P; LYIMO, BA; MSUYA, MH; IREMA, MN \& SCHREINER,A. 1994: AIDS education for primary school children in Tanzania: an evaluation study. AIDS, 8(8), 1157-1162.

KUHN, L; STEINBERG, M \& MATHEWS, C 1994: Participation of the school community in AIDS education: An evaluation of a high school programme in South Africa. AIDS Care. 6(2), 161-171.

MACNAIR-SEMANDS, RR; CODY, WK \& SIMONO, RB 1997: Sexual behaviour change associated with a college HIV course. Aids Care. 9(6), 727- 
MACNEIL, J \& HOGLE, J 1998: Applying social, behavioral and evaluation research to developing country HIV prevention programs. AIDS. 12(2), 99-107.

MCCLINTOCK, CG 1972: Experimental Social Psychology. New York: Holt Rinehart and Winston Inc.

MCKENNY, F; LORION, RP \& ZAX, $M$ 1976: Effective Behavior and $\mathrm{Hu}-$ man Development. New York:

McMillan Publishing Co. Inc.

MCMILLAN, JH \& SCHUMACHER, S 1997: Research in Education: $A$ concerted introduction, $3^{\text {rd }} \mathrm{ed}$, New York: Harper Collins College Publishers.

REBER, AS 2001: The Penguin Dictionary of Psychology. Rosebank: Penguin Books

ROSNOW, R \& ROSENTHAL, $R$ 1996: Beginning behavioural research: A Conceptual Primer. Englewood Cliff: Prentice Hall.

SAAL, FL \& KNIGHT, PA 1995: Industrial/Organizational Psychology: Science and Practice, $2^{\text {nd }}$ ed. Pacific Grove: Brooks/Cole Publishing Co.

SHAPIRO, J; RADECKIE, S; CHARCHIAN, $S \&$ JOSEPHSON, $V$ 1999: Sexual Behaviour and AIDS related Knowledge among Community College Students in Orange County, California. Journal of Community Health. 24(1), 29-43.

SIKKEMA, KJ; WINNET, RA \& LOMBARD DN 1995: Development and Evaluation of an HIV-risk reeducation program for female college students. AIDS Education and Prevention, 7(2), 145-159.

SOUTH AFRICA HIV \& AIDS STATISTICS 2008: The South A frican HIV \& AIDS Statistics Summary. http://www.avert.org/safricastats.htm. Accessed on 14 April, 2008.

STEYN, R \& MAPHOSO, LS 2005: Micro or macro approach to suicide prevention? Preliminary results with a small sample. Mental Health and Psy-
Psychotherapy, African Chapter. 1, 245256.

SWANEPOEL, E 2005: Exploring the impact of HIV/AIDS prevention messages. New Voices in Psychology. 1, 151-158.

TURNER, JC; GARRISON, CZ; KORPITA, E; WALLER, J; ADDY, C; HILL, WR \& MOHN, LA 1994: Promoting responsible sexual behaviour through a College Freshman Seminar. AIDS Education and Prevention. 6(3), 266-277.

WALTERS, AS 1997: The influence of homophobia in HIV/AIDS education. Journal of Psvchology and Human Sexuality. 9, 17-38.

WAYERS, ML 2002: HIV/AIDS Training and Awareness: A handbook. Pretoria, Police Social Work Services.

WEHMEIER, S 2000: Oxford Advanced Learner's Dictionary of Current English. Oxford: Oxford University Press.

WIERSON, MH \& BRIGHT J 1996: Educational Policy, Adolescent Knowledge of HIV Risk, and Sexual Behaviour in Zimbabwe and the United States. Claremont Symposium on Applied Psychology. London: Sage Publication.

WILRY, K; EDWARDS, J \& DILWORTH, D 1991: Effect of an AIDS issue course on college student's knowledge and attitude related to AIDS/HIV infection College of Student Journal. 25, 411-416.

WORLDBANK 2001: Best practices and Case Studies. http:// www.worldbank.org/urban/hivaids/ index.htm Accessed on 02 March 2005.

World Book 1992: World Book Encyclopedia. Chicago: World Book Inc. 


\section{HIVIAIDS KNOWLEDGE, ATTITUDE, AND BEHAVIOUR QUESTIONNAIRE (HAKABQ) PRE TEST}

NB:

1 This questionnaire is confidential

2 The questionnaire is for research purposes only

3 Answer as honest as you can

4 Mark the answer with X

(Confidential)

\section{SECTION 1}

\section{BIOGRAPHICAL INFORMATION}

ATTENDANTNO:

AGE:

RANK:

GENDER:

PSA Act

Police Act

Support Services

Detective Services

Operational Services

\section{SECTION 2}

\section{HIVIAIDS KNOWLEDGE}

\begin{tabular}{|c|c|c|c|c|}
\hline ItemNO. & STATEMENT & RESPONSE & & \\
\hline 1 & Coughing and sneezing do not spread HIV. & True & False & Don't know \\
\hline 2 & $\begin{array}{l}\text { A person can contract HIV by sharing a glass of water } \\
\text { with someone who is HIV positive. }\end{array}$ & True & False & Don't know \\
\hline 3 & $\begin{array}{l}\text { Withdrawing the penis before a climax (ejaculates) pre- } \\
\text { vents a woman from contracting HIV during sex. }\end{array}$ & True & False & Don't know \\
\hline 4 & A man can contract HIV if he has anal sex with a man. & True & False & Don't know \\
\hline 5 & $\begin{array}{l}\text { Condoms are less than fifty percent safe for the pre- } \\
\text { vention of HIV/AIDS infection. }\end{array}$ & True & False & Don't know \\
\hline 6 & $\begin{array}{l}\text { All pregnant women infected with HIV will have ba- } \\
\text { bies infected with HIV. }\end{array}$ & True & False & Don't know \\
\hline 7 & $\begin{array}{l}\text { Showering and washing your genitals after sex can } \\
\text { reduce the chances of being infected with HIV. }\end{array}$ & True & False & Don't know \\
\hline 8 & $\begin{array}{l}\text { Fruits, vegetable, and Mopani worms can help people } \\
\text { living with HIV/AIDS. }\end{array}$ & True & False & Don't know \\
\hline 9 & $\begin{array}{l}\text { I know where and how I can do HIV testing and } \\
\text { counseling, and the consequences of my testing. }\end{array}$ & True & False & Don't know \\
\hline
\end{tabular}




\begin{tabular}{|c|c|c|c|c|}
\hline ItemNO. & STATEMENT & RESPONSI & & \\
\hline 10 & I know about peer educators in my component. & True & False & Don't know \\
\hline 11 & $\begin{array}{l}\text { People are likely to contract HIV by deep kissing } \\
\text { (putting their tongues in their partners' mouth) if their } \\
\text { partners are HIV positive. }\end{array}$ & True & False & Don't know \\
\hline
\end{tabular}

\section{SECTION 3}

\section{HIVIAIDS ATTITUDE}

Answer on a 4 point scale with:

\begin{tabular}{|c|c|c|c|c|}
\hline $\mathbf{Y}$ & Definitely Yes & $\mathbf{y}$ & $=$ & Probably Yes \\
\hline$=$ & Definitely No & & $\mathbf{n}$ & Probably No \\
\hline
\end{tabular}

\begin{tabular}{|c|c|c|c|c|c|}
\hline ItemNo. & ATTITUDE & $\mathbf{R A}$ & & & \\
\hline 1 & Using a condom takes the "wonder" of sex. & $\boldsymbol{Y}$ & $\boldsymbol{y}$ & $n$ & $\boldsymbol{N}$ \\
\hline 2 & $\begin{array}{l}\text { If I do HIV testing, people will discriminate against me if they find } \\
\text { that I am HIV positive. }\end{array}$ & $\boldsymbol{Y}$ & $\boldsymbol{y}$ & $n$ & $\boldsymbol{N}$ \\
\hline 3 & $\begin{array}{l}\text { A condom is not necessary when you and your partner agree not to } \\
\text { have sex with anyone else. }\end{array}$ & $\boldsymbol{Y}$ & $y$ & $n$ & $N$ \\
\hline 4 & $\begin{array}{l}\text { I do not want to do testing because the person who conducts the } \\
\text { testing will make my results known to my colleagues. }\end{array}$ & $\boldsymbol{Y}$ & $y$ & $n$ & $N$ \\
\hline 5 & I like attending HIV/AIDS meetings, workshops and seminars. & $\boldsymbol{Y}$ & $\boldsymbol{y}$ & $n$ & $N$ \\
\hline 6 & Using a condom shows my partner that I care about him/her. & $\boldsymbol{Y}$ & $\boldsymbol{y}$ & $n$ & $\boldsymbol{N}$ \\
\hline 7 & People who use condoms sleep around a lot. & $\boldsymbol{Y}$ & $\boldsymbol{y}$ & $n$ & $N$ \\
\hline 8 & I can use the same toilet facilities with HIV positive people. & $\boldsymbol{Y}$ & $y$ & $n$ & $\boldsymbol{N}$ \\
\hline 9 & $\begin{array}{l}\text { Traditional medicines are a waste of time in the HIV/AIDS interven- } \\
\text { tion. }\end{array}$ & $\boldsymbol{Y}$ & $y$ & $n$ & $N$ \\
\hline 10 & Do you think peer educators can improve HIV/AIDS awareness? & $\boldsymbol{Y}$ & $\boldsymbol{y}$ & $n$ & $\boldsymbol{N}$ \\
\hline 11 & People who are HIV positive should mix with other people. & $\boldsymbol{Y}$ & $y$ & $n$ & $\boldsymbol{N}$ \\
\hline 12 & $\begin{array}{l}\text { I can die earlier if I know that I am HIV positive, than if I do not know } \\
\text { my HIV status. }\end{array}$ & $\boldsymbol{Y}$ & $y$ & $n$ & $\boldsymbol{N}$ \\
\hline
\end{tabular}

\section{SECTION 4}

\section{HIVIAIDS BEHAVIOUR}

Tick how you will rate yourself

\begin{tabular}{|c|l|l|l|l|}
\hline ItemNO. & STATEMENT & \multicolumn{2}{l|}{ RESPONSE } \\
\hline 1 & I use condom during sex & Not at all & Sometimes & Always \\
\hline 2 & I have done an HIV test in the past year. & Not at all & Sometimes & Ahways \\
\hline
\end{tabular}




\begin{tabular}{|c|c|c|c|c|}
\hline 3 & I have many sexual partners. & Not at all & Sometimes & Always \\
\hline 4 & $\begin{array}{l}\text { I usually attend HIV/AIDS meetings, workshops and } \\
\text { seminars. }\end{array}$ & Not at all & Sometimes & Always \\
\hline 5 & I avoid risky sexual partners. & Not at all & Sometimes & Always \\
\hline 6 & $\begin{array}{l}\text { I only have sex with an HIV negative partner, who only } \\
\text { has sex with me. }\end{array}$ & Not at all & Sometimes & Always \\
\hline 7 & $\begin{array}{l}\text { I talk with my sexual partner about HIV/AIDS before } \\
\text { having sex with him/her. }\end{array}$ & Not at all & Sometimes & Always \\
\hline 8 & $\begin{array}{l}\text { I always withdraw and wash my genitals (private parts) } \\
\text { after climaxing (ejaculation). }\end{array}$ & Not at all & Sometimes & Always \\
\hline 9 & I want to be involved with HIV/AIDS activities. & Not at all & Sometimes & Always \\
\hline 10 & I only have sex with people who had an HIV test. & Not at all & Sometimes & Always \\
\hline 11 & I eat fruits and vegetable regularly. & Not at all & Sometimes & Always \\
\hline
\end{tabular}

End of questionnaire. Thanks for your time. 